President:

Secretary:

Treasurer:

Business Manager:

Membership subseriptions:
P. A. P. Moran

D. G. HURLEY

v. G. HART

P. D. Best

Institutions:

Other members:

\section{Australian National University}

Department of Mathematics, The University of Western Australia, Nedlands, W.A. 6009.

Department of Mathematics, University of Queensland, St Lucia, Qld 4067

\title{
A\$145
}

A\$20 (which may be reduced to half for undergraduates and junior graduates)

Reciprocity agreements: Such agreements have been made with a number of other mathematical societies. Under the agreements members of the other societies who are not normally resident in Australia may join the Australian Mathematical Society at half the current rates.

Membership and correspondence: Applications for membership, notice of change of address or title or position, and other correspondence, except as noted below, should be sent to the Secretary. Subscriptions and correspondence related to accounts should be sent to the Treasurer. Correspondence about the distribution of the Society's GAZETTE, JOURNAL and BULLETIN, and orders for back numbers, should be sent to the Business Manager.

Members receive the Gazette free and are entitled to purchase other publications at the follow ing rates:
Journal-Series A A\$10 per year
Journal-Series B A\$2.50 per year
Bulletin A\$10 per year
OTHER PUBLICATIONS OF THE SOCIETY
THE JOURNAL SERIES A (PURE MATHEMATICS)

Editor: Professor J. B. Mruer,
Department of Mathematics,
Monash University,
Clayton, Vic. 3168.

Two volumes of four parts are published at a price of A\$36 per volume, in 1977. Manuscripts should be sent to the Editor or an Associate Editor listed in Series A.

THE BULLETIN of the Australian Mathematical Society began publication in 1969. Two volumes of three numbers are published annually. Manuscripts for publication should be sent to the Editor:
Dr B. H. Neumann,
Department of Mathematics, Institute of Advanced Studies, Australian National University, POB 4, Canberra, A.C.T. 2600.

The Australian Mathematical Society GAZETTE started publication in 1974 and carries news items, mathematical articles of general interest, and articles on tertiary mathematics teaching. Manuscripts for publication should be sent to the Editor:

\author{
Dr D. C. HuNr \\ School of Mathematics, \\ University of New South Wales, \\ Kensington, NSW 2033.
}

\section{Copyright by Australlan Mathematical Soclety 1978}

Copyright. Apart from any fair dealing for scholarly purposes as permitted under the Copyright Act, no part of this JoURNAL may be reproduced by any process without written permission from the Treasurer of the Australian Mathematical Society. 


\section{PREPARATION OF MANUBCUITS}

Authors of articles mubmitted for publileation in the Journal axe asked to envare thet thelr manuscripts are in a form suitable for eeading to tho printer. The neceseary preparation ahould be done by the author befoce initial rubaninion. We set out below a belef statemonat of the mante polats wo ack authors to observe.

1. The author whould submit 2 copies to the Bditor or an appropriate Amociate Beilter and keep a complete cops of the article.

2. An abetract (not ewoeding 250 word) should scosmpany cach copy of the mnouneript.

3. Manusoripts should be typed, oa hioh quallty A4 or quarto bond paper, one side onib with

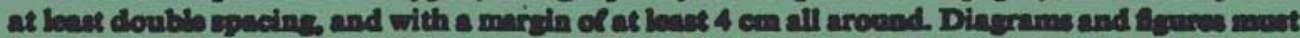
be submitted in a form autable for reproduction. IF THIS TITLI IS LONG, 8UPRLY AISOA BEORTENIDD FORM OF TEIB TITLB NOT BXCBEDING 40 LETTER, INCLUDING

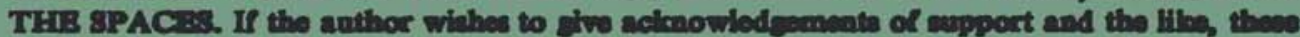
ahould be given in the introduction or at the eed of the article, or by a footenote attached to the name of the authoc. A maliation is shown at the end of the article, not at the besinning

4. The conventions of the manual for suthoes of Mnthematioal pepen by the American Minthemntienl soclety should be ueed, but relerenoes in the teat to other articles listed at the end

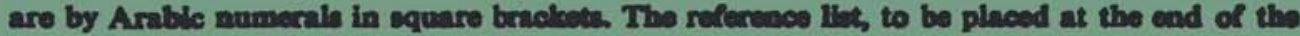
paper, should be ALPHABBTICAL ORDBR of names of the firet author. A typieal ingout is ghowe below.

[1] J. D. Fahelby, W. T. Read and W. Shockley, "Anisotropic elanticity with applications to dillocation theory", Aesa MCt. 1 (1953), 251-259.

[2] A. E. Green and W. Zerne, Thooretioal dastictry (O.U.P. It edition, 1954), Chapter 9.

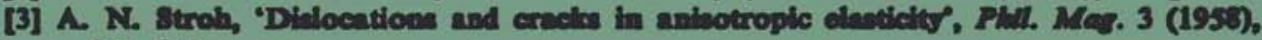
625-646.

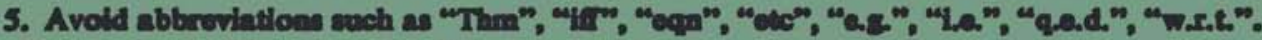
Spoilting and use of byphons should be coneinteint.

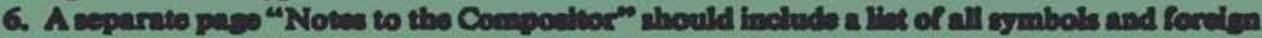
lettect.

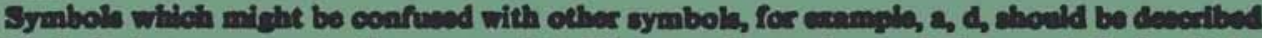

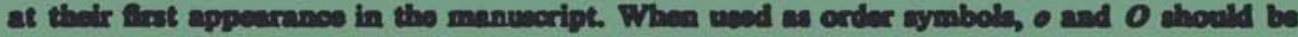
shown as 9,0 (cap).

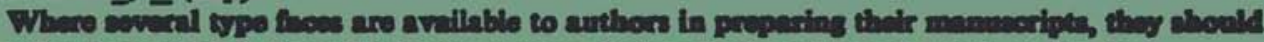

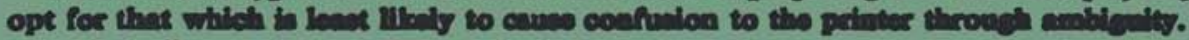

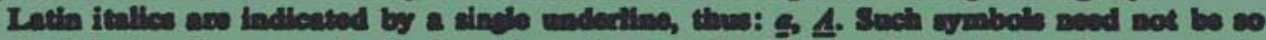

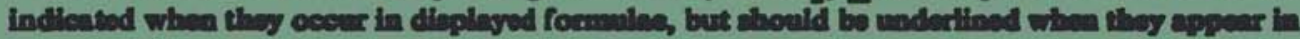

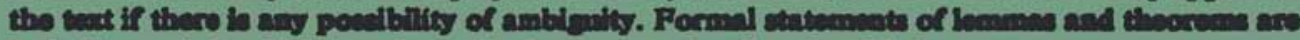
in itallos and should be so shown in the manusecripe. See aleo 7 below.

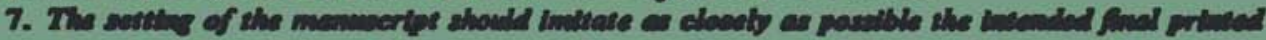

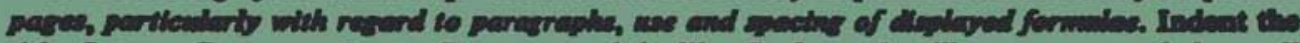

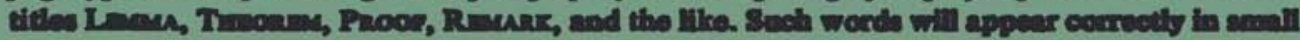
eapitals if they are underilined thos:

\section{Lenes}

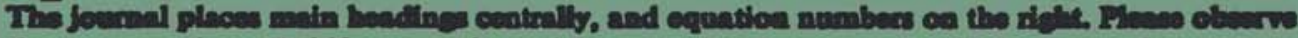
these eanvontione Boldenes type is uned for main hesdinges and should bo showa thens:

\section{Prellingering}

